\title{
Study on the Eligibility of Unregistered Chattel Mortgagee as the Applicants for Realizing Security Interests Cases
}

\author{
Linqi Li ${ }^{1, \text { a }}$, Yuanyuan Shen ${ }^{2, b}$ \\ ${ }^{1}$ School of Law, Henan Normal University, Xinxiang 453007, China \\ ${ }^{2}$ School of Law, Henan Normal University, Xinxiang 453007, China

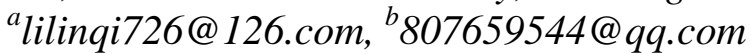

Keywords: security interests cases; chattel mortgage; register; applicant; eligible

\begin{abstract}
In realizing security interests cases, the eligible applicants are the key to the people's court's filing. The Civil Procedure Law and Judicial Interpretation of Civil Procedure Law did not clear whether the unregistered chattel mortgagee belongs to the eligible applicant for realizing security interests, and the unregistered chattel mortgage lacks the credibility of the registration system, which makes the academic circles have different views on it. The unregistered chattel mortgagee belongs to the eligible applicant for realizing security interests cases, because the rules on the realization of mortgage in the Property Law did not distinguish between chattel mortgage and real estate mortgage, the existence of substantive disputes is allowed in the application of non-litigation procedures, and it can be supported by comparative law.
\end{abstract}

\section{Introduction}

In realizing security interests cases, the eligible applicant is the precondition for initiating the non-litigation procedure for realizing security interests. It is not only related to the applicant's right to appeal, but also the correct exercise of the jurisdiction of the people's court. The precise definition of the scope of the applicant in realizing security interests cases is the first to be clear in the process of judicial practice, it is also a problem to be faced in the study of the non-litigation procedure of realizing security interests, which has a great influence on the realization of the legislative purpose of the non-litigation procedure for realizing security interests and the maintenance of the normal order of the entire judicial system. This article mainly discusses the issue of the eligibility of the unregistered chattel mortgagee as the applicant for realizing security interests cases.

\section{Legal Provisions for the Applicants of Realizing Security Interests Cases}

Article 196 and 197 of the "Civil Procedure Law" stipulate the procedural rules for realizing security interests. Interested parties affected by the procedural result are fully involved in the process, which is the most basic requirement of the principle of "due procedure," and also the most important condition for meeting the procedural justice. [1] In order to avoid the party of realizing security interests is blocked at the "entrance" in seeking judicial remedy, it is particularly important and necessary to clearly define the scope of the applicant of realizing security interests cases. Article 196 
of the "Civil Procedure Law" stipulates the applicant for realizing security interests cases, namely "the security interest holder and any other party entitled to request realization of the security interest." However, there are no specific and clear provisions for the subjects of "the security interest holder" and "any other party entitled to request realization of the security interest." In view of the unscientific demarcation of the scope of the applicant of the "Civil Procedure Law" regarding the realization of security interests, Article 361 of the "Judicial Interpretation of the Civil Procedure Law" clearly stipulates the scope of the applicant for realizing security interests cases: the security interest holders include the mortgagee, pledgee, and lien holder; any other party entitled to request realization of the security interest include the mortgagor, the pledgor, the debtor or the owner who has been left with the property.

Although "Judicial Interpretation of Civil Procedure Law" has refined the provisions of the applicant for realizing security interests cases in the "Civil Procedure Law," making the scope of the "the security interest holder" and "any other party entitled to request realization of the security interest” is more explicit, the relevant security interest holder and any other party entitled to request realization of the security interest have a more clear legal basis for the people's court to auction and sell the security property, and the grass-roots people's court also have relatively clear standard for the examination of the applicant's qualifications in the process of dealing with the realization of security interests cases, there are still some deficiencies. For example, Whether or not the unregistered chattel mortgagee belongs to the security interest holder under Article 196 of the "Civil Procedure Law" has not been clearly stipulated.

3. The Dispute of Whether the Unregistered Chattel Mortgagee can be Regarded as the Eligible Applicant in Realizing Security Interests Cases

In the practice of security in China, the establishment of chattel mortgage has different characteristics from real estate mortgage, that is, the registration has different effects in the real estate mortgage and the chattel mortgage. According to Article 187 of the "Property Law," if a mortgage is set up with real estate, the mortgage interest to take effect at the time of registration of mortgage. that is to say, for real estate mortgages, the "Property Law" of China takes the principle of entry into force after registration. For the establishment of chattel mortgage, the "Property Law" takes the registration of antagonism. Article 188 stipulates that the chattel mortgage is created at the time when the mortgage contract becomes valid; if the mortgage interest is not registered at the registration authority, it shall not be used to against a bone fide third party. The "Property Law" takes registration antagonism for the establishment of chattel mortgage, and while it is conducive to the protection of transaction safety, the unregistered chattel mortgage in real life lack the credibility of the registration system. Therefore, for whether the unregistered chattel mortgage rights can be regarded as the eligible applicant in realizing security interests cases, academic circles have two different opinions: affirmative theory and negative theory.

\subsection{Affirmative Theory}

It is affirmed that, due to the lack of the credibility of the registration system, although the unregistered chattel mortgage will produce certain risks in the judicial practice in realizing the rights through the realization of non-litigation procedures for security interests, the right of the mortgagee cannot be deprived to initiate non-litigation procedures. the unregistered chattel mortgagee shall be able to be the applicant for realizing security interests cases, and the substantive disputes can be resolved through litigation. [2] 


\subsection{Negative Theory}

It is negated that the important reason for the realization of mortgage rights through non-litigation procedures is the credibility of mortgage. Therefore, only the registered mortgage can be used to realizing non-litigation procedures for security interests. The absence of the publicity and credibility of the registration system of the unregistered chattel mortgage makes the existence of mortgage have many uncertainties, and it also loses the basis of the application of the no-litigation procedure, so the mortgagee is not an eligible applicant. [3]

\section{The Unregistered Chattel Mortgagee belongs to the Eligible Applicant for Realizing Security Interests Cases}

This article holds that the unregistered chattel mortgagee belongs to the security interest holder under Article 196 of the "Civil Procedure Law," and it has the right to be the applicant for the initiation of non-litigation procedure for realizing security interests, and the relevant legislation should clarify it. The main reasons are as follows:

\subsection{The Rules on the Realization of Mortgage in the "Property Law" did not Distinguish between Chattel Mortgage and Real Estate Mortgage}

Property have an important position in civil and commercial law, and movable property and real estates are the most basic and important classifications of things in civil law of various countries since the Roman law. In China, with regard to the classification of "objects," the "Property Law" establishes the dichotomy between movable and real estates in the "General Provisions" section. The preceding paragraph of Article 2 of Paragraph 2 of the "Property Law" stipulates: "The term 'property' as mentioned in this law includes real estates and movable property," and based this to construct the relevant rules and regulations in the "Property Law." [4]

In the mortgage interest system, according to the different collateral, the mortgage can be divided into chattel mortgage and real estate mortgage. Collateral as movable property is called chattel mortgage, collateral as real estate is called real estate mortgage, and chattel mortgage and real estate mortgage are very different in the establishment and other aspects. China's "Property Law" stipulates the establishment of chattel mortgages and real estate mortgages respectively. The real estate mortgage takes the principle of entry into force after registration, and the establishment of chattel mortgage is mostly based on mutual trust between the parties, the registration may increase the expenses of the mortgagor and influence the relationship between the parties, and the characteristic that movable is convenient to move also makes registration impossible to guarantee that the owner will dispose of the mortgaged property. In order to maintain the convenience of transactions, the establishment of chattel mortgage should be determined by the parties to decide whether or not to apply for mortgage registration.[5] Therefore, China's "Property Law" takes the registration of antagonism for the chattel mortgage, the countries around the world are usually also taken meaning in the establishment of chattel mortgage rights, whether or not to be registered when the mortgagee and mortgagor are given the right to choose according to their specific circumstances. According to Article 195 of the "Property Law" provisions, it can be seen that it does not distinguish between chattel mortgage and real estate mortgage. According to the explanation, all kinds of mortgagee have the right to "request the people's court to auction and sell the mortgaged property," all of which can be used as the applicant to initiate the non-litigation procedure of realizing security interests to realize creditor's rights. The unregistered chattel mortgagee can also initiate the non-litigation procedure as the applicant. 


\subsection{The Existence of Substantive Disputes is Allowed in the Application of Non-litigation Procedures}

The application of non-litigation procedures allows the existence of substantive disputes, but does not deal with substantive disputes. The realization of the security interest through the non-litigation procedures stipulated in the "Civil Procedure Law" allows the existence of substantive disputes in the application of non-litigation procedures, and in fact it may not completely avoid the existence of substantive dispute. Because conflicts and disputes are an unavoidable phenomenon in the development of human society, it is a social norm. [6] With the development of modern society, not only the subject of conflicts and disputes is diversified, but also the contents of conflicts and disputes are more complicated due to a large number of factors and many uncertainties in the process of generation. Therefore, to resolve conflicts and disputes, diversified judicial remedy systems are needed to make the people's courts handle civil cases as individualized as possible, so that the procedural needs of the parties receive attention and care. The setting of non-litigation procedures is an institutional effort, but the complexity of conflicts and disputes determines that non-litigation procedures that mainly resolve non-litigation cases will also have substantive disputes in their application.

China's security interest system is plentiful and complex. The realization of security interests involves multiple parties. In the application of the non-litigation procedures for realizing security interests, the existence of substantive disputes is difficult to avoid completely. The unregistered chattel mortgage may have more potential substantive disputes because of the lack of credibility of the registration system. However, according to the nature of non-litigation procedures for realizing security interests and the basic value they pursue, the non-litigation procedure for realizing security interests in China has many particularity and independence in program design compared with ordinary trial procedures, which is mainly reflected in the judgment of first instance shall be final in the trial system, the applicant dissatisfied with the people's court of the referee can not appeal; the trial organization adopts the system of sole judge proceedings in principle, only major and difficult cases adopt the collegiate system; the time limit for the conclusion of the case is short, it is 30 days from the date of filing; and it can not be applied to trial supervision procedures. Such a program design determines that it does not deal with substantive disputes, nor does it make refereeing decisions on issues involving substantive disputes.[7] After the unregistered chattel mortgages have initiated the non-litigation procedure and the relative person puts forward the substantive dispute, the non-litigation procedure can be terminated according to the provisions of Article 179 of the "Civil Procedure Law," and the interested person shall lodge a lawsuit with the people's court separately, so that the substantive dispute in the unregistered chattel mortgage may be settled through the litigation procedure, the right holder cannot be disqualified as an eligible applicant due to possible substantive disputes.

\subsection{Comparative Law has Similar Regulations in Taiwan of China}

From the perspective of the comparative law, the relevant legislation in the Taiwan of China allows unregistered chattel mortgagee to initiate non-litigation procedure as the applicant. Chattel mortgage in Taiwan is also take the registration of antagonism, if the mortgage interest is not registered at the time of establishment, it shall not be used against a bone fide third party. With regard to the realization of chattel mortgage, there are different provisions regarding the ways in which the mortgagee can negotiate the mortgage with the mortgagor in the Taiwan Region and Article 195 of the "Property Law" of China. According to Article 15 and 17 of the "Moving Asset Secured Transactions Act” in Taiwan, "The mortgagee has the right to occupy the mortgaged property when 
the debtor fails to perform the due debt or the mortgagor sells, pledges, relocates, transfers or otherwise disposes of the mortgaged assets to endanger the exercise of the mortgage, if the mortgagor refuses to hand over the mortgaged property, the mortgagee may apply to the court for enforcement. the mortgagee occupies the mortgaged property, and if the debtor still fails to perform the debt within the specified performance period, the mortgagee may sell or auction the mortgaged property, and shall be paid for the payment of the sale price to realize its claim.” With regard to specific procedures, Article 18 of the "Moving Assets Security Exchange Act" of the Taiwan region stipulates: "the mortgagee shall notify the debtor or third party before three days when the mortgagee implements possession of collateral in accordance with the first paragraph of the preceding article, the foregoing notice shall specify the cause and the time limit for fulfilling the contract. If the debtor fails to perform the contract when it expires, the mortgagor obtains possession of the mortgaged property, and the debtor may not request foreclosure after the sale. Without the first notice, When the mortgagee directly occupies the mortgaged property, if the debtor or a third person fulfills the contract within ten days after the creditor's possession of the mortgaged property, and the person who bears the cost has the foreclosure property, however, the collateral is corrupted, or its value is significantly reduced, which is enough to hinder the rights of the mortgagee, or if its cost of custody is excessive, the mortgagee must sell immediately after he has taken possession.” Article 19 stipulates: "If the mortgaged property is a detachable person and the auction price is sufficient to pay off the debt and expenses, it should be stopped immediately. The creditor or his family member should also participate in the auction to buy the mortgaged property."

If the chattel mortgagee does not sell or auction on its own for various reasons after taking possession of the mortgaged property, it may also apply for auction of collateral by the court. This is because the chattel mortgage and real estate mortgage all belongs to security interests. The real estate mortgagee can apply to the court to auction the mortgaged property under the provisions of Article 873, paragraph 1 of the "Civil Law," If the chattel mortgagee does not sell or auction on its own account while holding collateral, it has the same right to apply for a court to auction the collateral. The "Non-litigation Law" also has corresponding regulations, such as the provision of Article 73 of the "Non-litigation Law" in Taiwan. In the judicial practice, for the chattel mortgagee who applied for the court to auction the mortgaged property, at the summary of the general meeting of the people's court in August 22, 1972 (2) , "the supreme court" of the Taiwan region pointed out: "When the chattel mortgagee does not auction on his own, and apply for auction of collateral to the court, the court shall decide whether to permit it or not." It can be seen that in the Taiwan region of China, the unregistered chattel mortgagee can realize its mortgage by initiating non-litigation procedures, allowing unregistered chattel mortgagees to initiate non-litigation procedures as the applicant, which can be supported by comparative law.

\section{Conclusion}

In realizing security interests cases, for the parties involved in secured transactions who want to obtain judicial judgment from the people's court, the initiation of the procedure is the first step that must be faced by them, and it has extremely important significance. If the application of the related person in the security interests cases is rejected by the court, the effect of initiating non-litigation procedures cannot be achieved, which means that the desire to seek judicial remedy and to obtain judicial judgment in the disputes of realizing security interests cases is frustrated. This article analyzes the legal status quo of the applicant for realizing security interests cases, introduces the dispute of whether the unregistered chattel mortgagee can be regarded as the eligible applicant in realizing security interests cases, and proposes the reason that the unregistered chattel mortgagee belongs to the eligible applicant for realizing security interests cases, so that to protect the legal rights 
and interests of parties in realizing security interests cases, to ensure the effective operation of non-litigation procedures for realizing security interests, to exercise the system value and function of non-litigation procedures for realizing security interests, and promote the continuous realization of judicial fairness and enhance judicial credibility.

\section{Acknowledgments}

This work was financially supported by the National Social Science Fund of China (Grant No.15BFX162), one of the achievements of Dr. Start-up project of Henan Normal University (Grant No. qd15104).

\section{References}

[1] [Japan] Taniguchi Anping, Procedure Justice and Litigation (Supplementary Version), translated by Wang Yaxin and Liu Rongjun, China University of Political Science and Law Press, 2002, p. 11.

[2] Wang Minghua, The Range of Parties and the Conditions for Realizing the Security Interests Cases, Shandong Justice. 2013(1).

[3] Xiao Jianguo, Chen Wentao, On the Construction of Non-litigation Procedures to Realize Mortgage Interests, Journal of University of Science and Technology Beijing (Social Sciences Edition). 2011(1).

[4] Yang Lixin, Study on Major Difficulties in General Principles of Civil Law, China Legal Publishing House. 2011, pp. 310.

[5] Wang Zejian, Civil Law Theory and Case Studies (Revised Edition), China University of Political Science and Law Press. 2005, pp. 287.

[6] Liao Yongan, Civil Litigation Theory Exploration and Procedure Integration Information, China Legal Publishing House. 2005, pp.9.

[7] Li Linqi, On the Effect of Non-litigation Licensing of Realizing Security Interests, Journal of Xiangtan University (Philosophy and Social Sciences). 2016(6). 